\title{
INDIANA LANDLORD-TENANT LAW: AN IMPORTANT STEP FORWARD IN THEORY NEEDS TO BE MADE ReAl in Practice
}

\author{
FLORENCE WAGMAN ROISMAN*
}

\section{INTRODUCTION}

In the 1970s, the United States experienced what has been described as a "revolution" in landlord-tenant law. ${ }^{1}$ At first, the revolution seemed to apply in Indiana as well as the vast majority of other states, but this development seemed stymied from 1999 until the 2019 decision of the Indiana Supreme Court in

* William F. Harvey Professor of Law and Chancellor's Professor, Indiana University Robert H. McKinney School of Law. I was part of the "revolution" described in this article, as one of several counsel in Javins v. First National Realty Corp., Edwards v. Habib, Brown v. Southall Realty, and some other pertinent cases. (Javins v. First Nat'l Realty Corp., 428 F.2d 1071 (D.C. Cir.), cert. denied, 400 U.S. 925 (1970); Edwards v. Habib, 397 F.2d 687 (D.C. Cir. 1968), cert. denied, 393 U.S. 1016 (1969); Brown v. Southall Realty Co., 237 A.2d 834 (D.C. Ct. App. 1968), cert. denied, 393 U.S. 1018 (1969).)

For assistance in preparation of this article, I am grateful to Jon Laramore, Professors Judith Fox, Fran Quigley, Joel Schumm, Frank Sullivan, Margaret Tarkington, and George Wright; Richard Humphrey of the Ruth M. Lilly Law Library, Ms. Barbara Beeker, and Karen DuVall (J.D. expected May 2022 and William Dominic Alter (J.D. expected May 2022. For some portions of the article, I have relied on the amicus curiae brief in Reynolds v. Capps, 968 N.E.2d 789 (Ind. Ct. App. 2012), that was submitted by Alison M. Becker, esq., then a Certified Legal Intern, and Professor Fran Quigley, on behalf of the Health and Human Rights Clinic at the Indiana University Robert H. McKinney School of Law (I did consult on that brief). I've benefitted from the good ideas of these and other people and an important correction by William Alter. For any errors or mistakes in judgment, I alone am responsible.

I dedicate this article to the memory of Norman Lefstein, Dean Emeritus of our law school, former Director of the Public Defender Service of the District of Columbia, a dear friend, and a brilliant, indefatigable advocate for justice, particularly for indigent criminal defendants. As he would have agreed, if we had housing justice, we would have far fewer criminal defendants.

This article was written before the COVID-19 pandemic and does not purport to address issues caused by the pandemic.

1. See Roger A. Cunningham, The New Implied and Statutory Warranties of Habitability in Residential Leases: From Contract to Status, 16 URB. L. ANN. 3, 6 (1979) ("the net result can accurately be characterized as a 'revolution' in American landlord-tenant law”); Edward H. Rabin, The Revolution in Landlord-Tenant Law: Causes and Consequences, 69 CORNELL L. REV. 517, 519 (1984) ("[T]he residential tenant, long the stepchild of the law, has now becomes its ward and darling. Tenants' rights have increased dramatically; the landlords' rights have decreased dramatically.") See also Mary Ann Glendon, The Transformation of American Landlord-Tenant Law, 23 B.C. L. Rev. 503 (1982); Florence Wagman Roisman, The Right to Remain: Common Law Protections for Security of Tenure: An Essay in Honor of John Otis Calmore, 86 N.C. L. Rev. 817, 829-31 (2008). 
Rainbow Realty Group v. Carter. ${ }^{2}$ That holding, enforcing the Indiana General Assembly's 2002 Landlord-Tenant statute, ${ }^{3}$ appears to bring Indiana into conformity with doctrine in almost all states. Peculiar procedures, however, inhibit the effective implementation of the legislation and the Rainbow Realty decision. Part I of this article discusses the doctrinal developments; Part II, the procedural changes that must be made to effectuate the decisions of the Indiana General Assembly and the Indiana Supreme Court.

\section{THE DOCTRINE}

Inspired in large part by the 1970 opinion of Judge J. Skelly Wright in Javins v. First National Realty Corp., many courts and legislatures adopted an impliedby-law warranty of habitability for residential leases, thus ending the doctrinal reign of caveat lessor in favor of a legally imposed duty on the part of a landlord to convey and maintain residential premises in habitable condition. ${ }^{4}$ These judicial decisions and legislative changes also abandoned the common law rule that covenants in a lease were independent and instead provided that tenants could enforce the habitability requirement in defending suits for possession. ${ }^{5}$ By 1980, these reversals had become the majority rule in U.S. jurisdictions, the rules of the Restatement of Property, and the doctrine espoused by the leading treatises in the U.S., the Uniform Residential Landlord and Tenant Act (URLTA), and the Model Residential Landlord-Tenant Code. ${ }^{6}$

Initially, the revolution appeared to take hold in Indiana as well as other states. In 1972, in Theis v. Heuer, the Indiana Supreme Court "first imported a warranty of habitability into conveyances of real property" when it held "that a

2. Rainbow Realty Grp., Inc. v. Carter, 131 N.E.3d 168 (Ind. 2019).

3. Landlord-Tenant Act, Pub. L. No. 92-2002, § 1(b), 2002 Ind. Acts 1013 (codified as amended at Ind. Code $\S 32-11-8$ ).

4. Javins v. First Nat'1 Realty Corp., 428 F.2d 1071 (D.C. Cir.), cert. denied, 400 U.S. 925 (1970); Robert S. Schoshinski, American Law of Landlord and Tenant § 3:16 (1980) (identifying Javins as "the leading warranty of habitability case").

5. SchoshinsKi, supra note 4, $\S 3: 22$ (stating in 1980 that most recent cases adopting the implied warranty of habitability hold "that the tenant's duty to pay rent is 'mutually dependent' upon the landlord's fulfillment of his implied warranty of habitability" so that "breach of the warranty may be raised as a defense to an action for rent" or "a defense in an unlawful detainer action or similar summary proceeding for possession based on nonpayment of rent"); see also the 2019 Cumulative Supplement for cases after 1980.

6. Cunningham, supra note 1, at 5-6 (stating that the 1977 Restatement (Second) of Property, accepting an implied-by-law warranty of habitability at the initiation and during the term of the tenancy, "approximate[d]" what was then a "majority rule"); id. at 7 (referencing the Uniform Residential Landlord and Tenant Act (URLTA) and the Model Residential LandlordTenant Code; see also Gerald Korngold, Whatever Happened to Landlord-Tenant Law?, 77 Neb. L. Rev. 703, 703-04 (1998); 3 Tiffany, Real Property § 908, Extinction or Suspension of RentUntenable Condition of Premises (3d ed.); 2 Powell on Real Property, $\S 168.04$ Habitability of the Premises (2019). 
warranty of fitness for habitation may be implied in a builder-vendor's sale of a new house to the first purchaser." "In 1976, in Barnes v. MacBrown, the Indiana Supreme Court "extended the protection of the implied warranty to subsequent purchasers of the house . .." In 1980, the Indiana Court of Appeals held in Breezewood Management v. Maltbie that a landlord could be found liable to his tenant for a breach of implied warranty of habitability.

There were other aspects of the landlord-tenant "revolution," and they, too, seemed to be spreading to Indiana. Another of Judge Wright's opinions, in Edwards v. Habib, had established the doctrine of "retaliatory eviction," modifying the common law rule that a landlord could end a periodic tenancy "for any reason or for no reason at all" with the powerful exception that the landlord could not terminate a tenancy if the reason were to punish the tenant for having complained about housing code violations. ${ }^{10}$ This, too, became the majority rule in U.S. jurisdictions, the rule of the Restatement of Property, and the doctrine espoused by the leading treatises in the U.S. and the Uniform Residential Landlord and Tenant Act. ${ }^{11}$ This change in doctrine, too, seemed to win favor in Indiana in the 1973 decision in Frampton v. Central Indiana Gas Co., where the Indiana Supreme Court cited Edwards and similar cases with approval and used retaliatory eviction by analogy to recognize a "public policy exception" to Indiana's at-will employment doctrine. ${ }^{12}$

In 1999, this movement in Indiana suffered a severe setback. In Johnson $v$. Scandia Associates, the Indiana Supreme Court reviewed the history of implied

7. Johnson v. Scandia Associates, 717 N.E.2d 24, 27 (Ind. 1999) (discussing Theis v. Heuer, 280 N.E.2d 300, 306 (Ind. 1972)).

8. Johnson, 717 N.E.2d at 27 (discussing Barnes v. Mac Brown \& Co., 342 N.E.2d 619, 621 (Ind. 1976)).

9. Breezewood Mgmt. Co. v. Maltbie, 411 N.E.2d 670, 675 (Ind. Ct. App. 1980). In a 1976 case, Old Town Dev. Co. v. Langford, the court of appeals had recognized that a residential lease "is essentially contractual in nature carrying with it mutually dependent covenants including an implied warranty of habitability and the full range of remedies for breach of contract. . ." Old Town Dev. Co. v. Langford, 349 N.E.2d 744, 764 (Ind. Ct. App. 1976) (discussed in Walter W. Krieger, Jr. \& Michael A. Shurn, Landlord-Tenant Law: Indiana at the Crossroads, 10 IND. L. REV. 591, 603 (1977)).

10. Edwards v. Habib, 397 F.2d 687 (D.C. Cir. 1968), cert. denied, 393 U.S. 1016 (1969).

11. Schoshinski, supra note 4, Chapter 12 and $\S 12: 8$ (regarding URLTA); "Retaliatory Eviction of Tenant for Reporting Landlord's Violation of Law," 40 A.L.R.3rd 753 (1973).

12. Frampton v. Central Indiana Gas Co., 297 N.E.2d 425, 428 (Ind. 1973). See, e.g., Breanca Merritt et al., Eviction Trends in Marion County (2010-2016), Ind. Univ. Pub. PoL'y Inst. CTR. FOR RES. ON INCLUSION AND SOC. POL'Y (2019), https://policyinstitute.iu.edu/doc/evictiontrends.pdf?utm_source=press-release\&utm_campaign=eviction_trends [https://perma.cc/8N7C5TAC] [hereinafter Eviction Trends] (stating that Indiana is one of only eight states that do not protect tenants against landlord retaliation). Despite this statement, Indiana does explicitly protect against retaliation victims or alleged victims of domestic violence. See IND. CODE §§ 32-31-9-8 and 32-31-9-7. In 2010, Indianapolis's City-County Council enacted, and the mayor signed, an ordinance prohibiting various retaliatory acts by landlords. 
warranty doctrine in Indiana, interpreted the court of appeals' decision in Breezewood narrowly, and rejected the principle that there is in residential leases an implied-by-law warranty of habitability or fitness for use. ${ }^{13}$ Instead, a majority of the Indiana Supreme Court in Johnson rejected the idea of a court-imposed implied-by-law warranty and recognized only an implied-in-fact warranty of habitability. The majority said that "absent explicit statutory or regulatory language imposing on landlords the obligation to warrant a codified standard of habitability in property rented as a residence, a housing code does not impose a warranty on the residential leasehold transaction." 14 The majority added that "even though an implied warranty of habitability is not imposed by law on every residential lease contract, it may be implied in fact in the agreement between landlord and tenants. . . . This seems the best way of viewing Breezewood."15 Justice Dickson dissented, "believing that an implied warranty of habitability in leased residential premises should be recognized as a matter of law."16 Justice Boehm concurred in the result, "agreeing with Justice Dickson that the law requires a[n implied-by-law] warranty of habitability," but concluding that the recovery sought in this case required a showing of negligence. ${ }^{17}$

In 2002, the Indiana General Assembly enacted comprehensive landlordtenant legislation, including Chapter 8, Landlord Obligations Under a Rental Agreement. ${ }^{18}$ Among other things, this statute requires that a landlord "deliver the rental premises ... in compliance with the rental agreement, and in a safe, clean, and habitable condition," "comply with all health and housing codes applicable" to the premises, and "provide and maintain ... in good and safe working condition, if provided on the premises at the time the rental agreement is entered into:" electrical, plumbing, sanitary, heating, ventilating, air conditioning, elevators, etc. ${ }^{19}$ The statute also directs that a "waiver of the application of this chapter . . by contract or otherwise, is void." ${ }^{20}$ The statute provides that a tenant "may not bring an action under this chapter unless" the tenant has given the landlord notice of noncompliance, the landlord has been given a reasonable amount of time to remedy the noncompliance, and the "landlord fails or refuses to repair or remedy the condition described in the tenant's notice." ${ }^{21}$ A tenant who prevails in a claim under this section may recover actual and consequential damages, attorney's fees, court costs, injunctive relief, and "any other remedy

13. Johnson, 717 N.E.2d at 30-31.

14. Id. at 30 .

15. Id. at $30-31$.

16. Id. at 32 .

17. Id.

18. Landlord-Tenant Act, Pub. L. No. 92-2002, § 1(b), 2002 Ind. Acts 1013 (codified as amended at IND. CODE $\S 32-31-8-5$ ). The statute was amended in 2008 to cover leases with options to purchase. IND. CODE $\S 32-3-8-1$, amended by Publ. L. No. 62-2008, $§ 4$.

19. IND. CODE $\S 32-31-8-5$ (2019).

20. IND. CODE $§ 32-31-8-4$ (2019).

21. IND. CODE $§ 32-31-8-6(2019)$. 
appropriate under the circumstances. ${ }^{22}$

One might well have thought that this legislation provided the statutory directive that the Indiana Supreme Court had found lacking in Johnson $v$. Scandia. In 2006, however, Chief Justice Shepard, in a separate opinion in City of Vincennes v. Emmons, a case involving inspections of rental housing, wrote as though the 2002 legislation had not been enacted, or had no effect. The state's apartment owners, as amici, had urged the court "to hold that even when a tenant complains about a housing code violation (say, a fire safety threat), the city cannot investigate the threat without going to court for a warrant." ${ }^{23}$ Chief Justice Shepard wrote:

We have been urged from time to time to impose a warranty of habitability on every Indiana residential lease as a matter of common law. I think we have been wise to decline these invitations . . . My assessment of this question has partly rested on the knowledge that most Indiana renters ... are protected by . . . local housing codes. . . . [Had the Court embraced the position urged by amici,] the resultant bowdlerizing of local ordinances protecting renters would have suggested, to me at least, that the idea of recognizing a general implied warranty of habitability would bear revisiting. ${ }^{24}$

The Emmons case had not involved arguments about a warranty of habitability, so there was no reason why Chief Justice Shepard (or any other member of the Indiana Supreme Court) would have considered the 2002 landlord-tenant legislation in that case.

Indeed, for many years after 2002, no argument about the landlord-tenant legislation made its way to the appellate courts of the state. Part of the explanation for this probably is that very few tenants are represented by counsel in landlord-tenant proceedings. ${ }^{25}$ Another part of the explanation probably is the peculiar bifurcated method that Indiana courts use in landlord-tenant cases. When suits for possession are brought in the small claims courts of Indiana, the court first holds a hearing on the right to possession, usually awarding possession to the landlord. If a tenant raises issues such as habitability, those usually are scheduled for a "damages" hearing to be held several weeks later. ${ }^{26}$ When tenants already have lost possession, they are unlikely to pursue appellate remedies.

22. IND. CODE $§ 32-31-8-6(d)$ (2019).

23. City of Vincennes v. Emmons, 841 N.E.2d 155, 163 (Ind. 2006) (Shepard, C.J., concurring).

24. Id.

25. See The Supreme Court of Indiana, 2017 Ind. Jud. Serv. Rep.: Judicial Year in REVIEw 139 (2017) [hereinafter Honored to Serve] (showing 11,236 cases in Marion County Small Claims Courts in which at least one litigant represented zieself during 2017). "Zieself" is a genderneutral pronoun encompassing "herself" and "himself." See W. Or. Univ., SafeZone, https:/www.wou.edu/wp/safezone/pronouns/ [https://perma.cc/M2S9-ALT5].

26. See Judith Fox, The High Cost of Eviction: Struggling to Contain a Growing Social Problem, 41 Mitchell Hamline L.J. Pub. Pol'y \& Practice (2020). 
There was, however, an occasional appellate reference after 2006 to issues relevant to habitability in residential leaseholds. In 2008, in Morton v. Ivacic, the Indiana Supreme Court considered a residential landlord-tenant case on appeal from a small claims court. Chief Justice Shepard, writing for a unanimous Court, applauded the "informality of litigating in small claims court" because it "promotes doing substantial justice in a relatively efficient way, conferring benefits on plaintiffs and defendants alike." ${ }^{27}$ The Court also summarily affirmed the bifurcated method in which such claims are adjudicated. ${ }^{28}$ But the Court held that the small claims court had violated both an Indiana statute (Indiana Code section 32-30-3-2) and the Fourteenth Amendment Due Process Clause by depriving the tenant of "a sufficient opportunity to present a defense" to the landlord's claim. ${ }^{29}$

The landlord's claim was based on his allegations that (a) the tenant owed rent and (b) an unauthorized person was living in the unit. The tenant proffered evidence to counter both allegations, but the judge declined to entertain the evidence, asserting that "where there's smoke there's fire" and "[u]ltimately, [the landlord is] going to get possession of the property." "The Indiana Supreme Court held that the small claims court's refusal to receive the proffered evidence violated Indiana Code section 32-30-3-02(a), which allows a tenant "to show cause why the judge should not remove the defendant from the property and put the plaintiff in possession," Indiana Code section 32-30-3-2(b), which provides that the tenant "may appear and present supporting testimony at the hearing on the order to show cause," and the U.S. Supreme Court's statement that Fourteenth Amendment Due Process requires "an opportunity to present every available defense." 31

The Indiana Court of Appeals applied the implied warranty of habitability to forms of homeownership not involved in previous litigation. In 2009, in Dinsmore v. Fleetwood Homes of Tennessee, Inc., the court of appeals reviewed the use of the implied warranty doctrine in Indiana and held that the doctrine applied to manufactured mobile homes as well as to "site-built" homes. ${ }^{32}$

In 2012, the Indiana Court of Appeals reversed another small claims court ruling for a landlord, holding, in Reynolds $v$. Capps, that a hearing conducted by a court reporter deprived the tenant of property without due process of law. ${ }^{33}$ In this case, also, the bifurcated process was challenged, but the court found it unnecessary to reach the question of its validity. ${ }^{34}$

27. Morton v. Ivacic, 898 N.E.2d 1196, 1197 (Ind. 2008).

28. Id. at $1199 \mathrm{n} .1$.

29. Id. at 1200.

30. Id. at 1198 .

31. Id. at 1199-1200 (quoting IND. CODE § 32-30-3-02 (2019) and Lindsey v. Normet, 405 U.S. 56, 66 (1972)).

32. Dinsmore v. Fleetwood Homes of Tenn., Inc., 906 N.E.2d 186, 192 (Ind. Ct. App. 2009).

33. Reynolds v. Capps, 968 N.E.2d 789, 792 (Ind. Ct. App. 2012).

34. Id. at 792 n.2. The challenge was brought by the Health and Human Rights Clinic of the Indiana University Robert H. McKinney School of Law, appearing as amicus curiae. 
In 2016, the court of appeals decided another case involving the landlordtenant statute. In Pinnacle Properties v. Oliver, tenant Oliver withheld a month's rent because her apartment's air conditioning unit did not function for a month in the Summer of $2015 .^{35}$ Oliver repeatedly notified Pinnacle of the problem. The small claims court held that Oliver "had a legal right to withhold rent for the month" pursuant to her lease and Indiana Code section 32-31-8-5. ${ }^{36}$ The trial court found that Oliver had timely notified Pinnacle of the problem.

On appeal, Pinnacle claimed that the lease required the tenant to give written notice of such a problem, but because Pinnacle did not provide a copy of the lease, the court of appeals declined to reverse the trial court on that ground. "Furthermore," the court of appeals said, the trial court had denied Pinnacle's claim on the separate, independent ground of Indiana Code section 32-31-8-5, but since the court of appeals affirmed on the basis of the lease, it was not necessary to address the statutory issue. ${ }^{37}$ The court designated this decision one that "shall not be regarded as precedent or cited before any court" save for limited purposes. ${ }^{38}$

Into this jurisprudential stew, on September 13, 2019, dropped the Indiana Supreme Court's decision in Rainbow Realty v. Carter. ${ }^{39}$ Writing for a unanimous Court, Justice Slaughter held that the agreement labeled a "rent-to-buy" contract was subject to the landlord-tenant statute as a "rental agreement" for a "dwelling unit." It followed, the Court held, that:

Plaintiffs were required to deliver the House to the Couple in a habitable condition, []§ 32-31-8-5(1), which they did not do. The Statutes also render the Agreement's purported waiver of their obligation as void. Id. $\S 32-31-8-4$. Thus, the trial court was correct in finding that Plaintiffs breached the statutory warranty of habitability. ${ }^{40}$

Without ever mentioning Johnson v. Scandia, the Indiana Supreme Court recognized that the landlord-tenant legislation entirely undermined the rationale of that decision. The landlord-tenant statutes, the Court said, "are not about vindicating parties' freely bargained agreements. They are, rather, about protecting people from their own choices when the subject is residential property and their contract bears enough markers of a residential lease." ${ }^{\prime 11}$

In the decision the Indiana Supreme Court was vacating, the court of appeals also had said that the landlord-tenant statute "requires a landlord to warrant a rental property's habitability, providing that, inter alia, '[a] landlord shall [. . .d]eliver the rental premises to a tenant in compliance with the rental agreement

35. Pinnacle Props. Dev. Grp., LLC v. Oliver, 59 N.E.3d 1102 (Ind. Ct. App. 2016).

36. $I d$. at *4 (citing IND. CODE $§ 32-31-8-5$ (2019)).

37. Id. at *6-8.

38. Id. at $* 1$.

39. Rainbow Realty Grp., Inc. v. Carter, 131 N.E.3d 168 (Ind. 2019).

40. Id. at 176 .

41. Id. at 177 . 
and in a safe, clean, and habitable condition."'42 The court of appeals, however, had held the agreement between the parties was not subject to the landlord-tenant statute because it was a contract of sale rather than a lease or rental agreement. The basis for this holding was the court of appeals' understanding that a lease must have "a definite term and a reversion to the lessor. . .."43 The Indiana Supreme Court rejected this understanding, noting that the landlord-tenant statute states that it applies to every "rental agreement" and the agreement between the parties here satisfied that definition. ${ }^{44}$

Thus, with its decision in Rainbow Realty, the Indiana Supreme Court seems to have brought Indiana into agreement with the vast majority of U.S. jurisdictions, the Restatement, and academic analysis with respect to an impliedby-law warranty of habitability in residential leases.

This is potentially an immensely important ruling, offering an opportunity to enforce standards of safety and habitability in housing. Thousands of Hoosiers live in dangerous, deteriorated units, bilked by landlords who brazenly defy law and morality. ${ }^{45}$ Public health, civic decency, and respect for the rule of law require that the obligations imposed on landlords by state legislation be enforced vigorously. ${ }^{46}$

Unfortunately, however, the Indiana Supreme Court's vindication of the legislative determination is not likely to have much impact unless substantial changes are made in the way in which landlord-tenant cases are adjudicated in

42. Rainbow Realty Grp., Inc. v. Carter, 112 N.E.3d 716, 722 (Ind. Ct. App. 2018) (quoting IND. CODE $§ 32-31-8-5)$.

43. Id. at 718 .

44. Rainbow Realty Grp., Inc. v. Carter, 131 N.E.3d 168, 175-76 (Ind. 2019). Even if, as the court of appeals assumed, the common law definition of a lease were relevant, the court of appeals' narrow definition of "lease" is unjustified. At common law, many leases are not "for a term": periodic tenancies and tenancies at will are not "for a term." See, e.g., Restatement (Second) of Prop.: Landlord and Tenant $\S 1.5 \mathrm{cmt}$. d (Am. Law Inst. 1977) ("Where the parties enter into a lease of no stated duration and periodic rent is reserved or paid, a periodic tenancy is presumed"); $i d$. at $\S 1.6 \mathrm{cmt}$. b ("Where the parties enter into a lease of no stated duration and no periodic rent is reserved or paid, a tenancy at will is presumed. Compare Comment $d$ to $\S 1.5$ (Periodic Tenancy), in which a "lease of no stated duration but with periodic rent reserved or paid is considered"); see also Joseph William Singer, Property $\S 7.1$ at 305 (5th ed. 2017) ("Leaseholds transfer possession for a fixed period of time (a term of years) or a renewable period (periodic tenancy) or exist at the will of the owner (tenancy at will)." Also, there is no requirement that the reversion to the landlord be explicitly stated: it is created with the leasehold. Schoshinski, supra note 4, at $\S 8: 3$ ("Upon the creation of a leasehold interest the lessor retains a reversion, a non-possessory interest in fee simple"). Indeed, the premise for the eviction action that began the Rainbow Realty litigation is that the landlord had a reversion.

45. See Fox, supra note 26, at 12-16 (discussing the "ample evidence that housing conditions especially in low-income neighborhoods, are quite bad"); $i d$. at 20-21.

46. See, e.g., the Amicus Brief of the State of Indiana in Support of Appellees in Rainbow Realty v. Carter, 2018 WL 9491318 (Ind. App.) at 5, Statement of Interest (referencing "the importance of the public's interest in safe and habitable housing ...”). 
Indiana. Part II describes the process and explains what changes must be made. ${ }^{47}$

\section{THE ADJUDICATION OF LANDLORD-TENANT CASES IN INDIANA}

In Indiana, landlord-tenant cases are heard in small claims courts. In most of the state - ninety-one of the state's ninety-two counties - small claims cases are heard in a division of either a Superior Court or a Circuit Court. ${ }^{48}$ In Marion County, however - the most populous in the state - small claims are heard in nine township-based courts. ${ }^{49}$ These courts long have been criticized for, among other things, "perceived favoritism toward plaintiffs' attorneys" and "toward highvolume filers" 50 "such as property managers and creditors in debt collection matters." ${ }^{.51}$ As the National Center for State Courts (NCSC) pointed out in 2014, these (and other) criticisms "have been present for at least the past twenty years. They were acknowledged . . . in the early 1990's and have not yet been adequately addressed or resolved." 52

The Small Claims Court Rules for Marion County were amended in 2014, ${ }^{53}$ but the perceived and real problems of unfairness in landlord-tenant cases continue there and throughout the state. Many landlord-tenant cases are resolved against tenants by default, and even when tenants do appear they usually are not represented by counsel. ${ }^{54}$ Most strikingly, however, even when tenants do appear, their defenses usually will not be heard: as noted above, the standard practice is for the court to enter a judgment for possession for the landlord and defer hearing the tenants' claims and defenses until a later date, usually several weeks after the

47. Days after the Indiana Supreme Court's decision in Rainbow Realty, on September 17, 2019, the Court of Appeals of Indiana upheld another claim under IND. CODE $§ 32-31-8-5$ and its attorneys' fees companion, § 32-31-8-6. Husainy v. Granite Mgmt., LLC, 132 N.E.3d 486 (Ind. Ct. App. 2019).

48. Nat'l Ctr. for State Courts, Final Report: Marion County, Indiana Small Claims Courts (2014) at 1 [hereinafter NCSC Report].

49. $I d$.

50. Id. at 2,22 .

51. Small Claims Task Force, Report on the Marion County Small Claims Courts (2012) at 5 [hereinafter Small Claims Task Force].

52. NCSC Report, supra note 48, at 22. The NCSC Report of 2014 built on the Indiana Supreme Court's Marion County Small Claims Courts Task Force Report of 2012 and the 1992 Report of the Judicial Study Commission of the Indianapolis Bar Association (discussed at NCSC Report at 1-2). The Supreme Court's Small Claims Task Force Report of 2012 also concluded that "the problems of the Marion County Small Claims Courts have been evident for many years and need to be addressed now." Small Claims Task Force, supra note 51, Letter of Transmittal.

53. NCSC Report, supra note 48 , at 4.

54. Honored to Serve, supra note 25, at 140 (showing 11,833 cases in Marion County Small Claims Court resolved by default in 2017); id. at 139 (showing 11,236 cases in Marion County Small Claims Court in which at least one litigant represented zieself during 2017); $i d$. at 141 (showing 65,470 small claims cases throughout the state resolved by default); id. at 146 (showing total filings in small claims courts as 195,160). 
tenant has left the property. ${ }^{55}$

There appears to be no statutory authority for this bifurcated procedure. Indiana Code section 32-30-3-1, which governs actions "for the recovery of possession of real estate," directs that "the defendant may appear and present supporting testimony at the hearing" "evidence or testimony" before issuing an order. As the Indiana Supreme Court pointed out in Morton v. Ivacic in 2008, Indiana Code section 32-30-3-2(a) allows a tenant "to show cause why the judge should not remove the defendant from the property and put the plaintiff in possession" and directs Indiana Code section 3230-3-2(b) that the "defendant may appear and present supporting testimony at the hearing on the order to show cause. ${ }^{.57}$ In addition, as the Indiana Supreme Court pointed out in Rainbow Realty, Indiana Code section 32-31-8-6 expressly grants a tenant a cause of action "to enforce an obligation of a landlord under this chapter." ${ }^{\prime 58}$ These statutes guarantee a tenant the right to raise a defense to a landlord's claim for possession of real property before the court decides the question of possession.

The statute allows determination other than a final adjudication only after consideration of such evidence and testimony and only if the plaintiff "has filed with the court a written undertaking in an amount fixed by the court and executed by a surety . . . to assure the payment of any damages the defendant may suffer. . . ." ${ }^{59}$ Indiana Code section 32-31-6 authorizes small claims courts to issue emergency possessory orders on behalf of a landlord against a tenant "if the tenant has committed or threatens to commit waste to the rental unit," but the statute specifies that " waste' does not include failure to pay rent," usual basis for suits for possession. ${ }^{61}$

The Indiana Supreme Court and the Indiana Court of Appeals have recognized that tenants must be allowed to present their defenses. In Morton v. Ivacic, the small claims court "effectively declined to hear evidence on a tenant's affirmative defenses to eviction": the Supreme Court "conclude[d] that the tenant was not given a sufficient opportunity to present a defense, and therefore

55. See text at supra note 26. An Indiana University Public Policy Institute study reported that "renters discussed uninhabitable living conditions, and refused to pay rent as a result of poor housing" even though, in the opinion of the report writers (in May 2019) "this type of nonpayment is still a lease violation and justification for eviction." Eviction Trends, supra note 12, at 3.

56. IND. CODE $\S \S 32-30-3-1(a)(2), 32-30-3-2(b)(2)$ (2019).

57. Morton v. Ivacic, 898 N.E.2d 1196, $1199-2000$ (Ind. 2008); IND. CoDE § 32-30-3-2(a)-(b) (2019).

58. IND. CodE § 32-31-8-6(a) (2019); see Rainbow Realty Grp., Inc. v. Carter, 131 N.E.3d 168, 178 (Ind. 2019).

59. IND. CODE $\S \S 32-30-3-5,-6(2019)$.

60. IND. CODE $\S \S 32-31-6-2,-3,-7$ (2019).

61. Eviction Trends, supra note 12, at 3 (citing "inability to pay rent" but not indicating any basis for believing that the fact of nonpayment is due to inability to pay and, indeed, explaining that renters "refused to pay rent as a result of poor housing"). 
reverse[d]." ${ }^{92}$ In Morton, the Indiana Supreme Court relied on its 1942 decision in Olds v. Hitzemann, stating that "[w]e determined long ago that in an ejectment action, '[a]ll legal and equitable defenses are provable under [a] general denial, and any state of facts which would invoke the aid of equity for relief against the claim ... would be a defense." "63

There is no basis for treating tenant defenses under the landlord-tenant statute differently from other defenses. When a tenant counters a claim for nonpayment by claiming that the tenant has paid the rent, that defense must be heard. This is Morton v. Ivacic. When a tenant counters a claim for nonpayment by claiming that rent should be abated because the landlord has not complied with the lease or the landlord-tenant statute, this defense has an equal claim to be heard. This, indeed, is Pinnacle Properties v. Oliver. ${ }^{64}$ Tellingly, the Small Claims Manual promulgated by the Indiana Judicial Center expressly contemplates that a tenant will be able to pay for essential repairs and deduct that cost from rent claimed. ${ }^{65}$ Obviously, this "right" is meaningless if the tenant cannot vindicate it at the time the landlord asserts the claim for rent due. ${ }^{66}$

This is not a case where the state has forbidden tenants to present defenses to landlords' suits for possession. To the contrary, as shown above, the General

62. Morton v. Ivacic, 898 N.E.2d 1196, 1197 (Ind. 2008).

63. Id. at 1200 (quoting Olds v. Hitzemann, 42 N.E.2d 35, 38 (Ind. 1942) (regarding default in superior court action for ejectment and immediate possession)). It is the case that in Morton the Court said that it affirmed the bifurcated procedure, but the holding of the case was a rejection of the bifurcated procedure, a requirement that the trial court consider the tenant's defense before rendering a judgment of possession. Moreover, this dictum was issued without considering the impact of Indiana Code section 32-31-8-6. In fact, the Court in Morton reversed the trial court's ruling for the landlord because, the Indiana Supreme Court held, the trial court had deprived the tenant of "a sufficient opportunity to present a defense." Id. at 1197. In reality, this was a rejection of the trial court's effort to bifurcate the proceeding and defer consideration of the tenant's defenses to a time after the judgment of possession.

64. Pinnacle Props. Dev. Grp., LLC v. Oliver, 59 N.E.3d 1102 (Ind. Ct. App. 2016). In Pinnacle Properties, both the trial court and the court of appeals recognized that the tenant's defense had to be considered at the same time as the landlord's claim.

65. Ind. Jud. Ctr., Small Claims Manual 20-21 (2014), https://www.in.gov/judiciary/ files/small-claims-manual.pdf [https://perma.cc/ZMZ2-X7VX].

66. The section of the Manual headed "What all Landlords and Tenants Should Know" states that "[i]f the landlord fails to make agreed repairs within a reasonable time after notice, the tenant may have them completed and deduct the cost from rent BUT ONLY FOR ESSENTIAL REPAIRS THAT THE LANDLORD HAS AGREED TO MAKE, AND ONLY IF A PRIOR REQUEST HAS BEEN MADE." Id. at 20-21. The statement in the Manual is inaccurate: the landlord need not have agreed to make the repairs. The statement in the Manual also is inaccurate as it says that "[a]s a general rule a landlord has no duty to make repairs to leased premises unless the landlord agrees to do so ..." Id. at 20. To the contrary, Indiana Code section 32-31-8-5 requires that a landlord "[c]omply with all health and housing codes applicable to the rental premises" and "[m]ake all reasonable efforts to keep common areas of a rental premises in a clean and proper condition." The Manual recites that it does not apply to the Marion County small claims courts. 
Assembly has specifically provided that tenants have defenses and that those defenses may be raised in landlords' suits. Indeed, in Morton v. Ivacic the Indiana Supreme Court relied on the U.S. Supreme Court's decision in Lindsey v. Normet, citing that case for the principle that due process includes "an opportunity to present every available defense." ${ }^{97}$

Nor does the generally abandoned doctrine of independence of covenants in a lease justify requiring a tenant's habitability defenses to be presented after eviction at a second hearing. The dependence of covenants in a lease has been recognized in Indiana at least since $1976 .{ }^{68}$ The dependence of landlord and tenant obligations also is implicitly recognized in the Indiana Supreme Court's decision in Rainbow Realty, Inc. v. Carter.

The bifurcated landlord-tenant hearing violates not only Indiana statutes but also the Indiana Constitution. Article I, Section 12 of the Indiana Constitution provides that "every [person], for injury done to ... property, ... shall have remedy by due course of law. Justice shall be administered freely, and without purchase, completely, and without denial; speedily, and without delay." ${ }^{69}$ The Indiana Supreme Court has recognized that with this Due Course of Law Clause "courts of this state are constitutionally bound by the basic concepts of fairness that are frequently identified with 'due process' in the federal constitution." ${ }^{.70}$ The Indiana Supreme Court has said that "[d]ue course of law provisions appear to stem from Sir Edward Coke's commentary on the Magna Carta." ${ }^{.71}$ In JournalGazette Co. v. Bandido's, Inc., the Court wrote:

The historical antecedent of Article I, Section 12 . . is vividly seen in Article 40 of the Magna Charta, which Coke restated as providing: [E]very Subject of this Realm, for injury done to him . . . may take his remedy by the course of the Law, and have justice and right for the injury done him, freely without sale, fully without any denial, and speedily without delay. Hereby it appeareth, that Justice must have three qualities, it must be [Free, for nothing is more iniquitous than justice for sale; Complete, for justice should not do things by halves; and Swift, for justice delayed is justice denied]. ${ }^{72}$

The concept embraces "the idea that the "very essence of civil liberty

67. Morton, 898 N.E.2d at 1199 (Ind. 2008) (citing Lindsey v. Normet, 405 U.S. 56, 66 (1972)). In Lindsey, the U.S. Supreme Court had held, inter alia, that states were not constitutionally required to allow tenants to raise defenses to landlords' suits for possession.

68. See Old Town Dev. Co. v. Langford, 349 N.E.2d 744, 764 (Ind. Ct. App. 1976), superseded, 369 N.E.2d 404 (1977); Walter W. Krieger, Jr. \& Michael A. Shurn, Landlord-Tenant Law: Indiana at the Crossroads, 10 IND. L. REV. 591, 603 (1977).

69. IND. ConsT. art. I, §12.

70. Sanchez v. State, 749 N.E.2d 509, 515 (Ind. 2001).

71. Id. at 514 .

72. Journal-Gazette Co. v. Bandido's, Inc., 712 N.E.2d 446, 448 (Ind. 1999) (Dickson, J., dissenting) (quoting Faith Thompson, Magna Carta: Its Role in Making of the English Constitution, 1300-1629, at 365 (1948) (quoting Sir Edward Coke, Second Charta Institute 55-56 (4th ed. 1671)). 
certainly consists in the right of every individual to claim the protection of laws, whenever he receives an injury.",73 The Indiana Supreme Court agreed "that, in general terms, this concept of fairness embraces the opportunity to present evidence relevant to a defense. . .."74 Justice literally is incomplete, done "by halves," when a claim is heard and resolved by judgment without consideration of defense.

In Morton v. Ivacic, the Indiana Supreme Court held that the Fourteenth Amendment Due Process Clause requires that the tenant have "an opportunity to present every available defense." $" 75$ To this, the Indiana court might have added the established proposition that the "fundamental requisite of due process of law is the opportunity to be heard . . . at a meaningful time and in a meaningful manner." $" 76$ The U.S. Supreme Court's unanimous decision in Armstrong v. Manzo is especially pertinent as it emphasizes that due process requires the opportunity to defend an initial hearing where the plaintiff has the burden of proof, and this requirement cannot be satisfied by a subsequent procedure at which the former defendant has the burden of proof. ${ }^{77}$

Landlord suits for possession generally are premised on claims of nonpayment of rent, and often the most important defense a tenant will have will be that the landlord has failed to deliver the premises in habitable condition or has failed to maintain the premises in compliance with local codes or the state statute. $^{78}$ If a tenant cannot present those defenses before a judgment of possession is entered, the tenant has been deprived of the opportunity guaranteed by Indiana Code sections 32-30-3-2(a), (b), and 32-31-8-6, the Indiana Constitution, and the U.S. Constitution.

\section{CONCLUSION}

Evictions are a substantial problem in Indiana. The state's rate of eviction actions filed and evictions effected is higher than the U.S. national rate. ${ }^{79}$ Marion County, with only 14 percent of the state's population, had 45 percent of eviction filings and 39.8 percent of eviction rates in the state ${ }^{80}$ before the 2020 pandemic.

73. Sanchez, 749 N.E.2d at 515 (quoting Marbury v. Madison, 5 U.S. 137, 163 (1803)).

74. Id.

75. Morton v. Ivacic, 898 N.E.2d 1196, 1199 (Ind. 2008) (citing Lindsey v. Normet, 405 U.S. $56,66(1972))$.

76. Goldberg v. Kelly, 397 U.S. 254, 267 (1970) (quoting Grannis v. Ordean, 234 U.S. 385, 394 (1914)) and Armstrong v. Manzo, 380 U.S. 545, 552 (1965)).

77. Armstrong v. Manzo, 380 U.S. 545, _ (1965). Timing is of course also the point of Goldberg v. Kelly, 397 U.S. 254 (1970) (requiring a pre-termination proceeding that satisfies due process).

78. Fox, supra note 26, at 4 (citing ongoing research project in three Indiana counties), at 18 , 20-22 (discussing efforts to raise habitability defenses).

79. Eviction Trends, supra note 12, at 1.

80. Id. at 2; see also id. at 4 (stating that from 2011 to 2016, Marion County experienced a ten percent increase in median gross rent while median household income remained stagnant). 
In a national study, three Indiana cities ranked high in evictions per number of rental homes: Fort Wayne 13th, Indianapolis 14th, and South Bend 18th. ${ }^{81}$

The simple filing of an eviction action "may result in lasting consequences that affect housing choices for tenants going forward"; it may, for example, put a tenant on a "tenant blacklist' regardless of the outcome of the case." entry of judgment against a tenant has even more severe consequences. Even if the landlord and tenant ultimately resolve their differences or the tenant ultimately prevails in a damages hearing, the entry of judgment against the tenant can "negatively impact the tenant's credit score and could result in judgment collection through wage garnishment and asset seizure." 83

The consequences of housing insecurity are severe. Much research has shown the financial, health, and community impacts of housing insecurity. In his prizewinning book, Evicted: Poverty and Profit in the American City, sociologist Matthew Desmond summarizes the research in half a dozen pages, showing that housing security makes people "better parents, workers, and citizens." 84 "Residential stability," he reports, "begets ... psychological stability, .. . school stability, [and] community stability. . ..." ${ }^{\prime 55}$ On the other hand, eviction "causes loss": the "likelihood of being laid off is roughly 15 percent higher for workers who have experienced an eviction"; and even a year after eviction "families experience 20 percent higher levels of material hardship than similar families who were not evicted. They go hungry. They endure sickness and cold." "[W6 "[W]ithout stable shelter," he concludes, "everything else falls apart." 87

The societal harms of eviction actions are compounded when the process of eviction is as obviously unfair as is the bifurcated process in Indiana, where

81. Eviction Ratings, Eviction LAB, https:/evictionlab.org/rankings/\#/evictions?r=United\% 20States $+\mathrm{a}=\mathrm{O}+\mathrm{d}=$ evictionRate+large_en.

82. Trends in New York City Housing Court Eviction Filings, NYU Furman Center, 2 (Nov. 2019), https://furmancenter.org/files/publications/NYUFurmanCenter_TrendsInHousing CourtFilings.pdf [https://perma.cc/SG2C-EHGL].

83. Id. at 3; see also Eviction Trends, supra note 12, at 3 (stating that "[e]victions can affect an individual's credit score and ability to find future housing. Once a tenant is evicted, the eviction ruling will often remain on his or her record regardless of whether that tenant reached a solution with the landlord." Moreover, "[p]revious research shows that unemployment and recent job loss are up to 22 percent higher among those with past evictions, suggests that unemployment can result from - as well as lead to - an eviction." (citing Matthew Desmond \& Carl Gershenson, Housing and Employment Insecurity among the Working Poor, 63 Social Problems 46, 46 (2016)).

84. Matthew Desmond, Evicted!: Poverty and Profit in the American City 295, 304 (2016). Desmond is a Professor of Sociology at Princeton University and a MacArthur "Genius" Fellow. The book won the 2017 Pulitzer Prize for General Nonfiction, the National Book Critics Circle Award, the Carnegie Medal, the PEN/John Kenneth Galbraith Award for Nonfiction, and the 2018 Harriet Beecher Stowe Prize. See Evicted, Evicted (last visited Jan. 13, 2020), http://evictedbook.com/books/evicted-tr. [https://perma.cc/9KDN-RR7S].

85. DeSMOND, supra note 84, at 296.

86. Id. at 296-97.

87. Id. at 300 . 
objective observers long have criticized "perceived favoritism toward plaintiff's attorneys" and "toward high-volume filers" "such as property managers and creditors in debt collection matters." ${ }^{" 89}$ Contempt for the entire judicial system is promoted by exposure to patently one-sided collection agencies functioning under the name of courts..$^{90}$ "The appearance of impropriety undermines public confidence in the judicial system. ..."91

The Indiana Supreme Court's welcome decision in Rainbow Realty is a significant advance in legal doctrine for the state. To translate that advance into genuine improvements in housing conditions, housing security, and true justice will require much more work. Ending the bifurcation of landlord-tenant proceedings is an important next step. ${ }^{92}$

88. NCSC Report, supra note 48, at 2, 22.

89. Small Claims Task Force, supra note 51, at 5. While these criticisms were focused on Marion County, they are applicable to the entire state (and, indeed, other states as well); See, e.g., DESMOND, supra note 84 (stating that housing courts generally function as "eviction assembly line[s]," where "due process has been replaced by mere process: pushing cases through").

90. See Tom R. Tyler, Why People Obey the Law (2006).

91. In re Garrard, 624 N.E.2d 68, 70 (Ind. Ct. App. 1993). See also Myers v. Crouse-Hinds Div. of Cooper Indus., 53 N.E.3d 1160, 1169 (Ind. 2016) (Rush, C.J., dissenting) (noting “[j]udicial authority is a fragile thing," and courts earn respect through the "integrity in our processes."); Republican Party v. White, 536 U.S. 765, 793 (2002) (Kennedy, J., concurring) ("The citizen's respect for judgments depends . . . upon the issuing court's absolute probity. Judicial integrity is, in consequence, a state interest of the highest order.").

92. Far more must be done. Neither allowing habitability defenses nor expressly protecting against retaliatory conduct nor providing counsel for tenants in eviction cases will cure the problems. See, e.g., Nicole Summers, The Limits of Good Law: A Study of Housing Court Outcomes, 29 J. AfFordable Hous. \& CMTY. Dev. L. 29 (2020). Effective solutions must focus "upstream" - on requiring landlord compliance with habitability standards as a condition of access to the courts and on providing an adequate supply of social housing for the three of four households who are eligible for federally subsidized housing and cannot secure it. See also Desmond Tutu Quotes, GoodREADS.COM (last visited Jan. 13, 2020), https://www.goodreads.com/quotes/954454there-comes-a-point-where-we-need-to-stop-just; State of the Nation's Housing 2019, JoINT Center for Housing Stud. OF HARVArd U., at 5 (2019), https://www.jchs.harvard.edu/sites/ default/files/Harvard_JCHS_State_of_the_Nations_Housing_2019.pdf [https://perma.cc/5VH2$\mathrm{SUKK}]$. These issues demand further attention. 